\title{
MYORG-related disease is associated with central pontine calcifications and atypical parkinsonism
}

\author{
Viorica Chelban, MD, MSc, MRCP, Miryam Carecchio, MD, PhD, Gillian Rea, MD, Abdalla Bowirrat, MD, PhD, \\ Salman Kirmani, MD, Luca Magistrelli, MD, Stephanie Efthymiou, MSc, Lucia Schottlaender, MD, PhD, \\ Jana Vandrovcova, PhD, Vincenzo Salpietro, MD, Ettore Salsano, MD, Davide Pareyson, MD, \\ Luisa Chiapparini, MD, Farida Jan, MD, Shahnaz Ibrahim, MD Prof, Fatima Khan, MD, Zul Qarnain, MD, \\ Stanislav Groppa, MD, PhD, Nin Bajaj, MD, PhD, Bettina Balint, MD, Kailash P. Bhatia, MD Prof, \\ Andrew Lees, FMedSci, FRCP, Patrick J. Morrison, CBE, MD, DSc, Nicholas W. Wood, MD, PhD, \\ Barbara Garavaglia, MD, PhD, and Henry Houlden, MD, PhD
}

Neurol Genet 2020;6:e399. doi:10.1212/NXG.0000000000000399

\section{Abstract}

\section{Objective}

To identify the phenotypic, neuroimaging, and genotype-phenotype expression of MYORG mutations.

\section{Methods}

Using next-generation sequencing, we screened 86 patients with primary familial brain calcification (PFBC) from 60 families with autosomal recessive or absent family history that were negative for mutations in SLC20A2, PDGFRB, PDGBB, and XPR1. In-depth phenotyping and neuroimaging investigations were performed in all cases reported here.

\section{Results}

We identified 12 distinct deleterious MYORG variants in 7 of the 60 families with PFBC. Overall, biallelic MYORG mutations accounted for $11.6 \%$ of PFBC families in our cohort. A heterogeneous phenotypic expression was identified within and between families with a median age at onset of 56.4 years, a variable combination of parkinsonism, cerebellar signs, and cognitive decline. Psychiatric disturbances were not a prominent feature. Cognitive assessment showed impaired cognitive function in $62.5 \%$ of cases. Parkinsonism associated with vertical nuclear gaze palsy was the initial clinical presentation in $1 / 3$ of cases and was associated with central pontine calcifications. Cerebral cortical atrophy was present in $37 \%$ of cases.

\section{Conclusions}

This large, multicentric study shows that biallelic MYORG mutations represent a significant proportion of autosomal recessive PFBC. We recommend screening MYORG mutations in all patients with primary brain calcifications and autosomal recessive or negative family history, especially when presenting clinically as atypical parkinsonism and with pontine calcification on brain CT.

\author{
Correspondence \\ Dr. Chelban \\ v.chelban@ucl.ac.uk \\ or Dr. Garavaglia \\ barbara.garavaglia@istituto-besta.it
}




\section{Glossary}

DAT $=$ dopamine active transporter; gnomAD $=$ Genome Aggregation Database MMSE $=$ Mini-Mental State Examination; PFBC $=$ primary familial brain calcification.

Primary familial brain calcification (PFBC) is a genetic neurodegenerative condition characterized by calcium deposition in the basal ganglia and other brain regions usually presenting with a combination of movement disorders, migraine, psychiatric, and cognitive impairment. The exact prevalence of PFBC is unknown, but population-based genomic analysis indicates that it is underestimated and underdiagnosed, ${ }^{1}$ with a molecular diagnosis achieved in only up to $50 \%$ of PFBC cases. ${ }^{2}$ The pathogenesis of $\mathrm{PFBC}$ involves calcium and phosphate homeostasis via mutations in SLC20A2 (OMIM: 158378) and XPR1 (OMIM: 605237) and endothelial integrity and function affecting the blood-brain barrier via mutations in PDGFB (OMIM: 190040) and PDGFRB (OMIM: 173410). Among these, mutations in SLC2OA2 account for approximately $45 \%$ of all autosomal dominant and de novo reported familial cases from diverse ethnicities. ${ }^{3}$ However, a large proportion of autosomal recessive PFBC remain undiagnosed. ${ }^{4}$ Recently, biallelic mutations in MYORG (OMIM: 618255) have been implicated in the pathogenesis of autosomal recessive PFBC in families of Chinese ${ }^{5}$ and French ${ }^{6}$ ethnicity. Here, we report a large multicentric cohort of ethnically diverse patients with biallelic variants in MYORG and broaden the phenotypic spectrum related to MYORG mutations.

\section{Methods}

\section{Patients}

Patients with an autosomal recessive or negative family history and confirmed clinical and radiologic diagnosis of PFBC were recruited from multiple centers. Genetic testing was performed on stored blood samples of patients with unidentified etiologies of PFBC. Ethnically, the families were of British, Italian, Irish, Pakistani, and Israeli origin. Secondary causes of brain calcification were excluded in all cases. All cases were negative for other PFBC-related genes (SLC20A2, PDGFRB, PDGBB, and $X P R 1)$ and had comprehensive phenotyping performed by neurogenetics specialists.

In cases with biallelic MYORG variants, the results from additional investigations were retrospectively analyzed based on chart review where available: neuroimaging with $\mathrm{CT}$ in all reported cases $(n=8)$, brain MRI $(n=4)$, dopamine active transporter (DAT) scan $(\mathrm{n}=2)$, and fluorodeoxyglucose-PET $(\mathrm{n}=2)$. Cognitive impairment was assessed by formal psychometry.

\section{Genetic testing}

DNA was extracted from peripheral blood. Whole-exome sequencing was performed in all families. An Illumina HiSeq4000 instrument (Illumina, San Diego, CA) was used to generate
$100 \mathrm{bp}$ paired-end reads. Alignment was performed using BWA (bio-bwa.sourceforge.net/) ${ }^{7}$ with GRCH38 as a reference. Variants were called using the GATK ${ }^{8-11}$ UnifiedGenotyperbased pipeline ${ }^{8-10}$ workflow. All variants were annotated using ANNOVAR $^{12}$ and filtered using custom R scripts. Only novel or very rare variants with a minor allele frequency of $<0.01$ in the 1000 Genomes Project ${ }^{13}$ and Genome Aggregation Database $(\mathrm{gnomAD})^{14}$ or known pathologic mutations were included. Variants were filtered for homozygous, compound heterozygous, highly deleterious, rare mutations segregating with the disease. Except for families 1 and 7, segregation was confirmed in all other families.

For every rare MYORG variant identified (ENST00000297625, GenBank transcript ID NM_020702), we determined pathogenicity and novelty. Pathogenicity was assessed using the American College of Medical Genetics and Genomics and the Association for Molecular Pathology recommendations for variant classification. ${ }^{15}$ Only pathogenic and likely pathogenic variants were included here. All pathogenic and likely pathogenic variants were confirmed with bidirectional Sanger sequencing. Primers are available in table e-1 (links.lww.com/ NXG/A227).

\section{Standard protocol approvals, registrations, and patient consents}

The individuals included in this study were recruited along with unaffected family members under ethics-approved research protocols (UCLH: 04/N034) with informed consent.

\section{Data availability}

Anonymized data used for this study are available from the corresponding authors on reasonable request. A data access agreement needs to be signed.

\section{Results}

\section{Genetic spectrum}

We screened 86 cases from 60 families with PFBC that were negative for pathogenic variants in SLC20A2, PDGFB, $P D G F R B$, and XPR 1 and had a recessive or negative family history. We identified pathogenic and likely pathogenic homozygous and compound heterozygous variants in MYORG (ENST00000297625, GenBank transcript ID NM_020702) in 8 cases from 7 families (figure e-1, links.lww.com/NXG/ A227). Overall, biallelic MYORG mutations accounted for $11.6 \%$ (7/60) of PFBC families in our cohort. We identified 12 distinct mutations, of which 4 were novel (figure 1A) and 8 were present in gnom $A D$ with very low allele frequency in the heterozygous state and absent in the homozygous state (table 


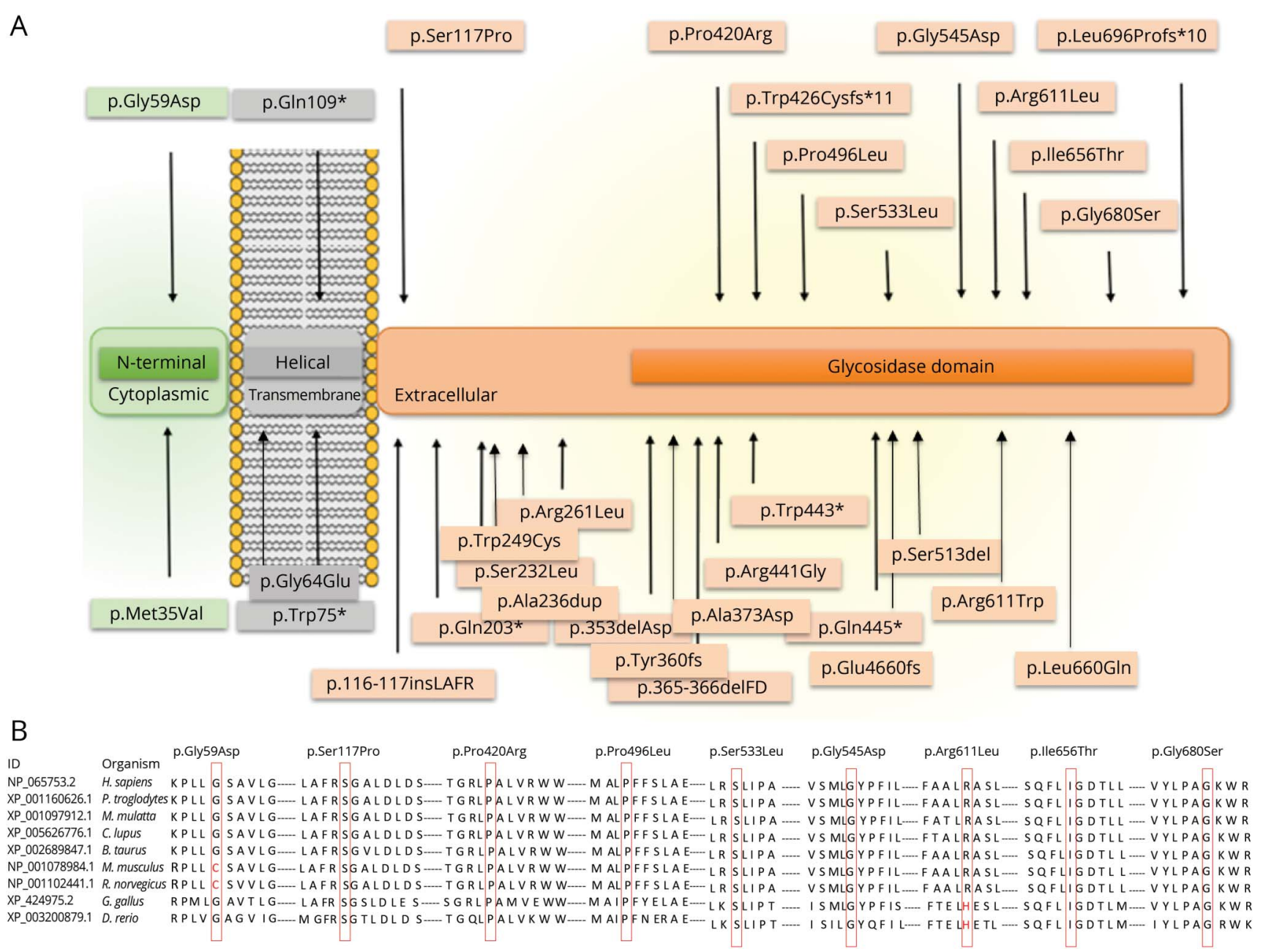

(A) Schematic representation of MYORG with all the mutations identified in our study and those reported to date. The MYORG functional domains and their cellular localization are indicated: green, $\mathrm{N}$-terminal sequence (cytoplasmic); gray, helical (transmembrane); orange, glycosidase domain (extracellular). The mutations reported in this cohort are plotted on top of the gene; mutations previously reported are below the gene. (B) Conservation across species for novel missense MYORG variants. The variants are marked with red boxes for the corresponding amino acid.

e-2). With the exception of 1 variant (p.Ile656Thr), none of the variants presented here have been previously reported in MYORG-related brain calcifications. Apart from copy number variants, all types of mutations have been found in this cohort ( 1 nonsense, 1 frameshift deletion, 1 insertion, and 9 missense variants). All missense variants were located in conserved and highly conserved amino acid positions (figure 1B). The 12 mutations identified in this study were located throughout the gene with no obvious mutational hotspots. Two mutations were inherited in the homozygous state in the 2 consanguineous families; the 5 nonconsanguineous families presented with compound heterozygous variants.

\section{Phenotype spectrum}

In our cohort, MYORG mutation carriers presented with a high phenotypic variability. The average age at onset was 59.1 years (median 56.4 years, range 39 years to incidental finding at 87 years). Symptoms at onset varied from parkinsonism (37.5\%), ataxia and/or dysarthria (37.5\%), and headache (12.5\%).
Insidious onset with brain calcifications found incidentally was in $12.5 \%$ of cases. Table 1 and table e-3 (links.lww.com/NXG/ A227) present clinical details of all MYORG-related cases included in this study.

An initial progressive parkinsonism associated with supranuclear gaze palsy phenotype was identified in $1 / 3$ of cases at disease onset. Case 1 presented at the initial clinical examination age 40 years with profound facial hypomimia with a staring expression, reduced up and down gaze, associated with profound bilateral bradykinesia, rigidity, reduced arm swings, and a combination of ataxia and freezing. She had poor response to levodopa. Case 5 presented at age 56 years with asymmetric parkinsonism and supranuclear gaze palsy with poor response to levodopa. Progressive deterioration of motor function, dysarthria, dysphagia, and gait ataxia became evident over the following years. Case 8 presented at age 62 years with parkinsonism, frequent falls, staring gaze with vertical gaze palsy that progressed over 16 years along with gait ataxia, cognitive 
Table 1 Phenotype description of all MYORG mutations reported in this study

\begin{tabular}{|c|c|c|c|c|c|c|c|c|}
\hline Case number & Case 1 & Case 2 & Case 3 & Case 4 & Case 5 & Case 6 & Case 7 & Case 8 \\
\hline Family number & 1 & 2 & & 3 & 4 & 5 & 6 & 7 \\
\hline $\begin{array}{l}\text { Ethnicity/ } \\
\text { country }\end{array}$ & Caucasian & Middle East & & Caucasian & & & & \\
\hline cDNA sequence & c.176G>A & c. $1611 C>T$ & c. $1611 \mathrm{C}>\mathrm{T}$ & c.1634G>A, c.1598C>T & $\begin{array}{l}\text { c.2211_2212del, } \\
\text { c.349T>C }\end{array}$ & c. $2162 \mathrm{G}>\mathrm{A}, \mathrm{c} .1383 \mathrm{C}>\mathrm{G}$ & c. $325 \mathrm{C}>\mathrm{T}$, c. $1832 \mathrm{G}>\mathrm{T}$ & $\begin{array}{l}\text { c.1401_- } \\
\text { 1402insCGCTGGTG, } \\
\text { c.1967T>C }\end{array}$ \\
\hline $\begin{array}{l}\text { Amino acid } \\
\text { change }\end{array}$ & p.Gly59Asp & p.Pro496Leu & p.Pro496Leu & $\begin{array}{l}\text { p.Gly545Asp, } \\
\text { p.Ser533Leu }\end{array}$ & $\begin{array}{l}\text { p.Leu696Profs*10, } \\
\text { p.Ser117Pro }\end{array}$ & p.Gly680Ser, p.Pro420Arg & $\begin{array}{l}\text { p.GIn109Ter, } \\
\text { p.Arg611Leu }\end{array}$ & $\begin{array}{l}\text { p.Trp426Cysfs*11, } \\
\text { p.lle656Thr }\end{array}$ \\
\hline Zygosity & Homozygous & Homozygous & & $\begin{array}{l}\text { Compound } \\
\text { heterozygous }\end{array}$ & $\begin{array}{l}\text { Compound } \\
\text { heterozygous }\end{array}$ & Compound heterozygous & $\begin{array}{l}\text { Compound } \\
\text { heterozygous }\end{array}$ & $\begin{array}{l}\text { Compound } \\
\text { heterozygous }\end{array}$ \\
\hline $\begin{array}{l}\text { Sex (male/ } \\
\text { female) }\end{array}$ & Female & Male & Male & Female & Female & Female & Male & Female \\
\hline $\begin{array}{l}\text { Age at } \\
\text { examination (y) }\end{array}$ & 41 & 52 & 46 & 87 & 72 & 81 & 67 & 68 \\
\hline Age at onset (y) & 39 & 51 & 45 & $\begin{array}{l}\text { Incidental finding } \\
\text { at } 87 y\end{array}$ & 56 & 73 & 62 & 62 \\
\hline Disease duration & $3 y$ & $1 \mathrm{y}$ & $1 \mathrm{y}$ & Unknown & $16 y$ & $8 y$ & $5 y$ & $6 y$ \\
\hline Disability & $\begin{array}{l}\text { Requires assistance with } \\
\text { most tasks }\end{array}$ & $\begin{array}{l}\text { Normal independent } \\
\text { daily living }\end{array}$ & $\begin{array}{l}\text { Normal } \\
\text { independent daily } \\
\text { living }\end{array}$ & $\begin{array}{l}\text { Normal independent } \\
\text { daily living }\end{array}$ & Bedridden & $\begin{array}{l}\text { Requires support for } \\
\text { walking }\end{array}$ & Independent & $\begin{array}{l}\text { Bedridden and needs } \\
\text { assistance for self-care }\end{array}$ \\
\hline $\begin{array}{l}\text { Symptom at } \\
\text { onset }\end{array}$ & Parkinsonism and ataxia & Headache & $\begin{array}{l}\text { Ataxia and } \\
\text { dizziness }\end{array}$ & Unknown & Parkinsonism & Progressive dysarthria & $\begin{array}{l}\text { Progressive dysarthria } \\
\text { and dysphagia }\end{array}$ & Parkinsonism \\
\hline \multicolumn{9}{|l|}{ Phenotype } \\
\hline Parkinsonism & Yes & Yes & No & Yes & Yes & Yes & Yes & Yes \\
\hline $\begin{array}{l}\text { Cerebellar } \\
\text { syndrome }\end{array}$ & $\begin{array}{l}\text { Gait ataxia and } \\
\text { dysarthria }\end{array}$ & Dysarthria & Limb ataxia & $\begin{array}{l}\text { Mild } \\
\text { dysdiadochokinesia; } \\
\text { wide-based gait }\end{array}$ & Dysarthria and ataxia & Dysarthria & Dysarthria & Dysarthria \\
\hline $\begin{array}{l}\text { Pyramidal } \\
\text { syndrome }\end{array}$ & Yes & No & No & No & Yes & No & No & No \\
\hline Dystonia & Yes & No & No & No & No & No & No & No \\
\hline $\begin{array}{l}\text { Eye } \\
\text { movements } \\
\text { and cranial } \\
\text { nerves }\end{array}$ & Supranuclear gaze palsy & Normal & Normal & Normal & $\begin{array}{l}\text { Supranuclear gaze } \\
\text { palsy, dysarthria, and } \\
\text { dysphagia }\end{array}$ & No & $\begin{array}{l}\text { Dysphagia and } \\
\text { dysarthria }\end{array}$ & $\begin{array}{l}\text { Supranuclear gaze } \\
\text { palsy and dysphagia }\end{array}$ \\
\hline $\begin{array}{l}\text { Psychiatric } \\
\text { symptoms }\end{array}$ & No & No & No & No & Depression & No & No & Depression \\
\hline
\end{tabular}


decline, urinary incontinence, and pyramidal signs. All cases presenting with parkinsonism and supranuclear gaze palsy had associated cognitive impairment characterized by executive dysfunction, poor verbal fluency, and concrete verbal reasoning with low scores on Mini-Mental State Examination (MMSE). Two of the 3 patients had a reduced tracer uptake on DAT scan consistent with symmetrical, bilateral marked loss of presynaptic dopaminergic neurons (particularly in the putamen).

A cerebellar-bulbar syndrome of variable severity was present in all our cases ranging from very mild (case 4) to moderate dysarthria and dysphagia affecting mainly speech and swallowing (cases 2, 6, and 7). Severe gait and limb ataxia was present in 3/8 of cases (cases 1, 3, and 5). Parkinsonism was detectable in 7 of 8 cases, often associated with other features including supranuclear gaze palsy, early frequent falls, early cognitive decline, and lack of response to levodopa.

One associated extrapyramidal sign in MYORG-related disease was limb dystonia. This was clinically presenting as dystonic posturing in the upper limb precipitated by walking. A third of our patients had bilateral pyramidal signs in the lower limbs. Other associated clinical features were headache ( 2 cases), urinary incontinence ( 2 cases), and cramps in the lower limbs ( 1 case).

Neuropsychiatric evaluation revealed 2 cases with depression. Cognitive assessment showed impaired cognitive function in $62.5 \%$ of cases, with different degrees of severity. MYORG patients showed reduced verbal fluency and poor verbal reasoning in the first year of disease (cases 1 and 3), mild memory impairment (case 2, MMSE 27/30) with progression over the following years (case 7, Montreal Cognitive Assessment 21/30 and case 8 , MMSE 23/30) to a diagnosis of dementia (case 5).

Response to levodopa in cases with parkinsonian phenotype was poor to moderate and proved particularly ineffective in patients with parkinsonism associated with supranuclear gaze palsy. Case 1 with confirmed DAT scan abnormality had some modest benefit from levodopa in the first year of treatment. However, the response to treatment was short lived and faded in the next 2 years of disease.

\section{Neuroimaging spectrum}

All patients showed extensive brain calcifications regardless of disease duration. Basal ganglia (putamen, internal globus pallidus, and caudate nucleus) were involved in all cases, whereas cerebellar hemispheres (folia and dentate nuclei) were involved in $75 \%$ of cases. Half of the cases also showed calcification of subcortical white matter. Extensive central pontine calcification was present in 3 cases. Cerebral cortical atrophy was observed in $37 \%$ of cases (figure $2 \mathrm{~A}$ ).

\section{Discussion}

In this study, we screened MYORG mutations in 86 cases from 60 unrelated, autosomal recessive PFBC families. We identified 7 


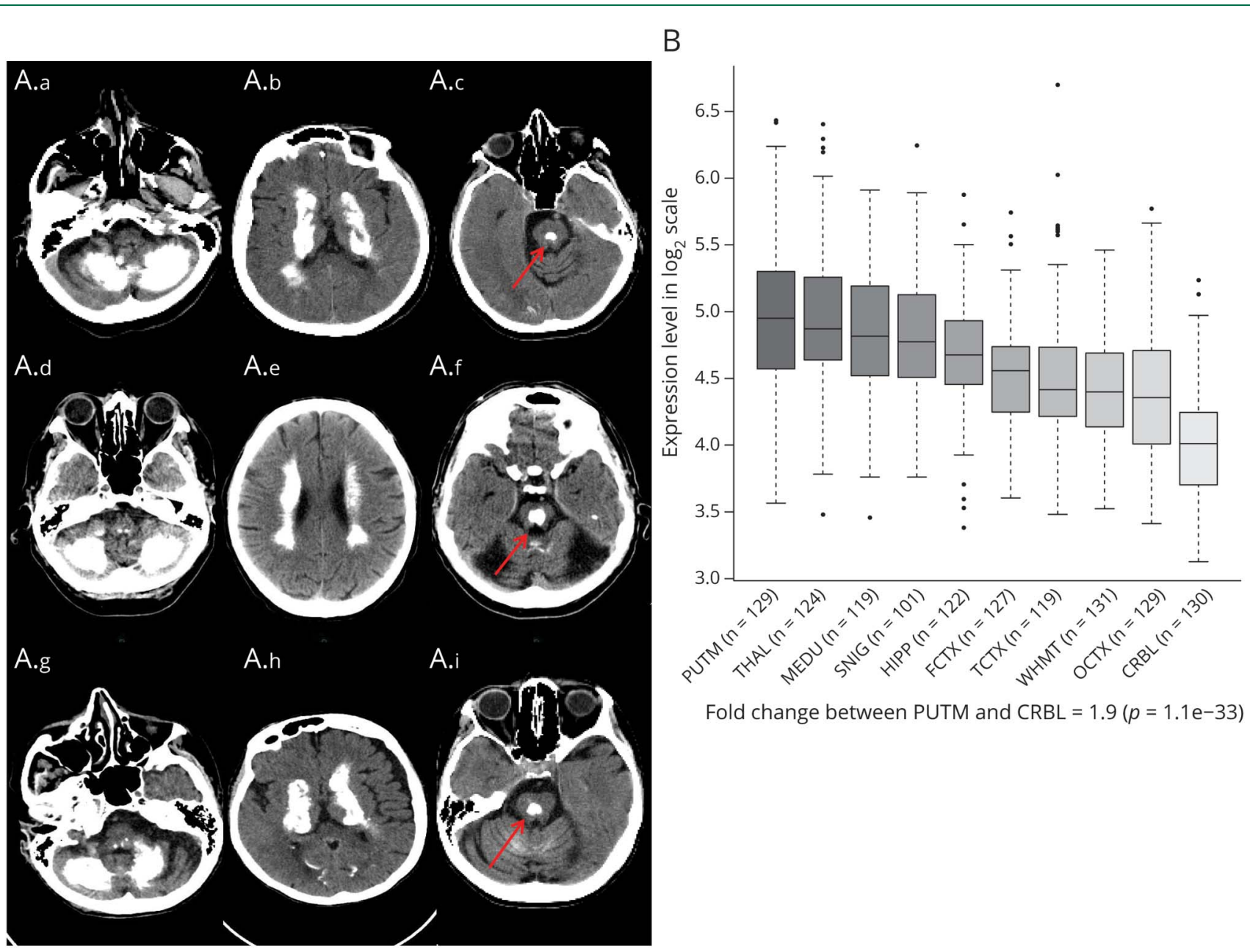

(A) Neuroimaging spectrum in MYORG cases. Cases 5 (A.a-A.c), 7 (A.d-A.f), and 8 (A.g-A.i) showed similar calcification pattern distribution with extensive involvement of cerebellar dentate nuclei and hemispheres, basal ganglia, thalami, and subcortical white matter; a characteristic central pontine calcification (red arrow) is present in all cases; frontotemporal and cerebellar atrophy was present in case 7; case 6: calcification of the internal globus pallidus, subcortical white matter, and dentate nuclei, with minimal involvement of thalami bilaterally. Severe frontotemporal and cerebellar atrophy is also detectable. (B) MYORG clinical spectrum correlates with MYORG gene expression in different brain areas. MYORG gene expression in different brain areas in adult pathologically normal human brains. ${ }^{25}$ MYORG is expressed in all 10 brain regions with highest expression detected in the putamen. $C R B L=$ cerebellum; FCTX = frontal cortex; HIPP = hippocampus; MEDU = medulla; OCTX = occipital cortex; PUTM = putamen; SNIG = substantia nigra; TCTX = temporal cortex; THAL = thalamus; WHMT = white matter.

new families of different ethnic backgrounds with disease-causing MYORG variants. Biallelic MYORG mutations were associated with PFBCs in $11.6 \%$ of families from our cohort. We identified 12 distinct mutations, suggesting that recurrent MYORG mutations are infrequent. Most of the initial reported cases came from consanguineous families. ${ }^{5,6}$ Here, we present a cohort largely lacking in known consanguinity, with the majority of mutations inherited in the compound heterozygous state.

Our data suggest that the majority of cases have a disease onset in late adulthood with a combination of dysarthria, ataxia, parkinsonism, and cognitive decline consistent with the phenotypes previously reported in MYORG mutations s,6,16-19 and other autosomal dominant PFBC-causing genes. ${ }^{20}$ However, parkinsonism with supranuclear gaze palsy was frequently observed (37.8\% of cases) in our cohort and has not been previously described in MYORG mutation carriers. Therefore, this further extends the phenotypic spectrum of MYORG-related disease. Of interest, central pontine calcification was present in over $1 / 3$ of cases, which seems to be a radiologic diagnostic clue for MYORG mutation carriers, as this anatomic region is typically not affected in other genetic PFBC cases. ${ }^{6}$ As physiologic brain calcifications in this age group are reported in up to $20 \%,{ }^{21,22}$ an association of calcifications, supranuclear gaze palsy, and parkinsonism with atypical features such as ataxia or rapid cognitive decline should prompt physicians to test for MYORG mutations in this subgroup of patients. We show that next-generation sequencing can contribute to the diagnosis of late-onset, mildly affected or asymptomatic cases, therefore providing a more comprehensive understanding of the genetic architecture of brain calcifications.

The exact mechanism leading to disease in MYORG mutations is still unknown. On a cellular level, the gene is 
expressed in astrocytes localized to the endoplasmic reticulum $^{5}$ and playing a role as glycosyl hydrolase. ${ }^{23} \mathrm{Al}-$ though gene expression (Genotype-Tissue Expression ${ }^{24}$ ) is reported highest in the basal ganglia (nucleus accumbens and caudate) after the skeletal muscle, gene expression data in BRAINEAC ${ }^{25}$ suggest that the putamen and the thalamus express the most MYORG messenger RNA followed by the medulla and the substantia nigra (figure 2B). These areas are mirrored in the clinical phenotype and calcification distribution on neuroimaging assessment in our cohort. Calcifications localized in the basal ganglia structures $(100 \%)$, followed by the cerebellum in $75 \%$ of our cases, subcortical white matter $(50 \%)$, and the thalamus $(50 \%)$.

The phenotype observed in individuals with biallelic deleterious MYORG variants suggests a high variability among and within families with a disease severity ranging from insidious, incidental findings to severe, rapidly progressing disease course. Asymptomatic cases with biallelic MYORG mutations $^{5}$ and heterozygous mutation carriers with punctate calcifications on the brain $\mathrm{CT}$ have been reported $\left.{ }^{5,6,16}\right)$. Our data together with previous reports suggest a dose-dependent phenotype based on the effect of mutations on the enzymatic activity of MYORG; however, no study has evaluated the enzymatic activity in MYORG mutations.

We show that biallelic MYORG mutations represent a significant proportion of PFBC cases without mutations in other known disease-causing genes. Here, we reported 12 distinct MYORG variants associated with brain calcifications and extended the phenotypic spectrum of this disease including atypical parkinsonism with pontine calcification. We recommend screening MYORG mutations in all patients with primary brain calcifications and autosomal recessive or negative family history.

\section{Acknowledgment}

The authors thank the participants and their families for their essential help with this work. They also acknowledge C. Panteghini, C. Reale, and F. Invernizzi (Neurogenetics Unit, Fondazione IRCCS Istituto Neurologico Carlo Besta) for their support in sample management.

\section{Study funding}

This work was supported by The Wellcome Trust (Synaptopathies strategic award [104033]) and the Medical Research Council (MRC UK International Centre and project grants). The Association of British Neurologists' Academic Clinical Training Research Fellowship andMSA Trust funded V.C. The authors acknowledge the "Cell lines and DNA Bank of Pediatric Movement Disorders and Mitochondrial Diseases" of the Telethon Network of Genetic Biobanks (grant GTB12001J), the EuroBioBank Network, and the Pierfranco and Luisa Mariani Foundation.

\section{Disclosure}

The authors report no disclosures. Go to Neurology.org/NG for full disclosure.

\section{Publication history}

Received by Neurology: Genetics September 16, 2019. Accepted in final form December 17, 2019.

\section{Appendix Authors}

\begin{tabular}{|c|c|c|c|}
\hline Name & Location & Role & Contribution \\
\hline $\begin{array}{l}\text { Viorica } \\
\text { Chelban, MD, } \\
\text { MSc, MRCP }\end{array}$ & $\begin{array}{l}\text { UCL Queen } \\
\text { Square Institute of } \\
\text { Neurology, } \\
\text { London, UK }\end{array}$ & Author & $\begin{array}{l}\text { Designed and } \\
\text { conceptualized the } \\
\text { study; acquisition of } \\
\text { data; analyzed the } \\
\text { genetic and clinical } \\
\text { data; and drafted the } \\
\text { manuscript for } \\
\text { intellectual content }\end{array}$ \\
\hline $\begin{array}{l}\text { Miryam } \\
\text { Carecchio, MD, } \\
\text { PhD }\end{array}$ & $\begin{array}{l}\text { University of } \\
\text { Padua, Italy }\end{array}$ & Author & $\begin{array}{l}\text { Acquisition of data; } \\
\text { interpreted the } \\
\text { imaging data; and } \\
\text { revised the } \\
\text { manuscript for } \\
\text { intellectual } \\
\text { content }\end{array}$ \\
\hline
\end{tabular}

Gillian Rea, MD Belfast City Author Acquisition of data
Hospital, UK $\quad$ and revised the manuscript for intellectual content

\begin{tabular}{|c|c|c|c|}
\hline $\begin{array}{l}\text { Abdalla } \\
\text { Bowirrat, MD, } \\
\text { PhD }\end{array}$ & $\begin{array}{l}\text { An-Najah National } \\
\text { University, Albiar } \\
\text { Village, Nablus, } \\
\text { Palestine }\end{array}$ & Author & $\begin{array}{l}\text { Acquisition of data } \\
\text { and revised the } \\
\text { manuscript for } \\
\text { intellectual content }\end{array}$ \\
\hline $\begin{array}{l}\text { Salman } \\
\text { Kirmani }\end{array}$ & $\begin{array}{l}\text { Aga Khan } \\
\text { University, } \\
\text { Karachi, Pakistan }\end{array}$ & Author & $\begin{array}{l}\text { Acquisition of data } \\
\text { and revised the } \\
\text { manuscript for } \\
\text { intellectual content }\end{array}$ \\
\hline $\begin{array}{l}\text { Luca } \\
\text { Magistrelli, MD }\end{array}$ & $\begin{array}{l}\text { Eastern Piedmont } \\
\text { University, } \\
\text { Novara, Italy }\end{array}$ & Author & $\begin{array}{l}\text { Acquisition of data } \\
\text { and revised the } \\
\text { manuscript for } \\
\text { intellectual content }\end{array}$ \\
\hline $\begin{array}{l}\text { Stephanie } \\
\text { Efthymiou }\end{array}$ & $\begin{array}{l}\text { UCL Queen } \\
\text { Square Institute of } \\
\text { Neurology, } \\
\text { London, UK }\end{array}$ & Author & $\begin{array}{l}\text { Acquisition of data } \\
\text { and revised the } \\
\text { manuscript for } \\
\text { intellectual } \\
\text { content }\end{array}$ \\
\hline $\begin{array}{l}\text { Lucia } \\
\text { Schottlaender, } \\
\text { MD, PhD }\end{array}$ & $\begin{array}{l}\text { UCL Queen } \\
\text { Square Institute of } \\
\text { Neurology, } \\
\text { London, UK }\end{array}$ & Author & $\begin{array}{l}\text { Acquisition of data } \\
\text { and revised the } \\
\text { manuscript for } \\
\text { intellectual content }\end{array}$ \\
\hline $\begin{array}{l}\text { Jana } \\
\text { Vandrovcova, } \\
\text { PhD }\end{array}$ & $\begin{array}{l}\text { UCL Queen } \\
\text { Square Institute of } \\
\text { Neurology, } \\
\text { London, UK }\end{array}$ & Author & $\begin{array}{l}\text { Analysis of data and } \\
\text { revised the } \\
\text { manuscript for } \\
\text { intellectual content }\end{array}$ \\
\hline $\begin{array}{l}\text { Vincenzo } \\
\text { Salpietro, MD }\end{array}$ & $\begin{array}{l}\text { UCL Queen } \\
\text { Square Institute of } \\
\text { Neurology, } \\
\text { London, UK }\end{array}$ & Author & $\begin{array}{l}\text { Acquisition of data } \\
\text { and revised the } \\
\text { manuscript for } \\
\text { intellectual content }\end{array}$ \\
\hline $\begin{array}{l}\text { Ettore Salsano, } \\
\text { MD }\end{array}$ & $\begin{array}{l}\text { Fondazione IRCCS } \\
\text { Istituto } \\
\text { Neurologico Carlo } \\
\text { Besta, Italy }\end{array}$ & Author & $\begin{array}{l}\text { Acquisition of data } \\
\text { and revised the } \\
\text { manuscript for } \\
\text { intellectual content }\end{array}$ \\
\hline
\end{tabular}


Appendix (continued)

\begin{tabular}{|c|c|c|c|}
\hline Name & Location & Role & Contribution \\
\hline $\begin{array}{l}\text { Davide } \\
\text { Pareyson, MD }\end{array}$ & $\begin{array}{l}\text { Fondazione IRCCS } \\
\text { Istituto } \\
\text { Neurologico Carlo } \\
\text { Besta, Italy }\end{array}$ & Author & $\begin{array}{l}\text { Acquisition of data } \\
\text { and revised the } \\
\text { manuscript for } \\
\text { intellectual content }\end{array}$ \\
\hline $\begin{array}{l}\text { Luisa } \\
\text { Chiapparini, } \\
\text { MD }\end{array}$ & $\begin{array}{l}\text { Fondazione IRCCS } \\
\text { Istituto } \\
\text { Neurologico Carlo } \\
\text { Besta, Italy }\end{array}$ & Author & $\begin{array}{l}\text { Acquisition of data } \\
\text { and revised the } \\
\text { manuscript for } \\
\text { intellectual content }\end{array}$ \\
\hline Farida Jan, MD & $\begin{array}{l}\text { Aga Khan } \\
\text { University, } \\
\text { Karachi, Pakistan }\end{array}$ & Author & $\begin{array}{l}\text { Acquisition of data } \\
\text { and revised the } \\
\text { manuscript for } \\
\text { intellectual content }\end{array}$ \\
\hline $\begin{array}{l}\text { Shahnaz } \\
\text { Ibrahim }\end{array}$ & $\begin{array}{l}\text { Aga Khan } \\
\text { University, } \\
\text { Karachi, Pakistan }\end{array}$ & Author & $\begin{array}{l}\text { Acquisition of data } \\
\text { and revised the } \\
\text { manuscript for } \\
\text { intellectual content }\end{array}$ \\
\hline Fatima Khan & $\begin{array}{l}\text { Aga Khan } \\
\text { University, } \\
\text { Karachi, Pakistan }\end{array}$ & Author & $\begin{array}{l}\text { Acquisition of data } \\
\text { and revised the } \\
\text { manuscript for } \\
\text { intellectual content }\end{array}$ \\
\hline Zul Qarnain & $\begin{array}{l}\text { Aga Khan } \\
\text { University, } \\
\text { Karachi, Pakistan }\end{array}$ & Author & $\begin{array}{l}\text { Acquisition of data } \\
\text { and revised the } \\
\text { manuscript for } \\
\text { intellectual content }\end{array}$ \\
\hline $\begin{array}{l}\text { Stanislav } \\
\text { Groppa, PhD }\end{array}$ & $\begin{array}{l}\text { Institute of } \\
\text { Emergency } \\
\text { Medicine, } \\
\text { Chisinau, Republic } \\
\text { of Moldova }\end{array}$ & Author & $\begin{array}{l}\text { Acquisition of data } \\
\text { and revised the } \\
\text { manuscript for } \\
\text { intellectual content }\end{array}$ \\
\hline $\begin{array}{l}\text { Nin Bajaj, MD, } \\
\text { PhD }\end{array}$ & $\begin{array}{l}\text { University of } \\
\text { Nottingham, UK }\end{array}$ & Author & $\begin{array}{l}\text { Acquisition of data } \\
\text { and revised the } \\
\text { manuscript for } \\
\text { intellectual content }\end{array}$ \\
\hline $\begin{array}{l}\text { Bettina Balint, } \\
\text { MD }\end{array}$ & $\begin{array}{l}\text { UCL Queen } \\
\text { Square Institute of } \\
\text { Neurology, } \\
\text { London, UK }\end{array}$ & Author & $\begin{array}{l}\text { Acquisition of data } \\
\text { and revised the } \\
\text { manuscript for } \\
\text { intellectual content }\end{array}$ \\
\hline $\begin{array}{l}\text { Kailash P. } \\
\text { Bhatia }\end{array}$ & $\begin{array}{l}\text { UCL Queen } \\
\text { Square Institute of } \\
\text { Neurology, } \\
\text { London, UK }\end{array}$ & Author & $\begin{array}{l}\text { Acquisition of data } \\
\text { and revised the } \\
\text { manuscript for } \\
\text { intellectual content }\end{array}$ \\
\hline $\begin{array}{l}\text { Andrew Lees, } \\
\text { FMedSci, FRCP }\end{array}$ & $\begin{array}{l}\text { UCL Queen } \\
\text { Square Institute of } \\
\text { Neurology, } \\
\text { London, UK }\end{array}$ & Author & $\begin{array}{l}\text { Acquisition of data } \\
\text { and revised the } \\
\text { manuscript for } \\
\text { intellectual content }\end{array}$ \\
\hline $\begin{array}{l}\text { Patrick J. } \\
\text { Morrison, CBE, } \\
\text { MD, DSc }\end{array}$ & $\begin{array}{l}\text { Belfast City } \\
\text { Hospital, UK }\end{array}$ & Author & $\begin{array}{l}\text { Acquisition of data } \\
\text { and revised the } \\
\text { manuscript for } \\
\text { intellectual content }\end{array}$ \\
\hline $\begin{array}{l}\text { Nicholas W. } \\
\text { Wood, PhD }\end{array}$ & $\begin{array}{l}\text { UCL Queen } \\
\text { Square Institute of } \\
\text { Neurology, } \\
\text { London, UK }\end{array}$ & Author & $\begin{array}{l}\text { Acquisition of data } \\
\text { and revised the } \\
\text { manuscript for } \\
\text { intellectual content }\end{array}$ \\
\hline $\begin{array}{l}\text { Barbara } \\
\text { Garavaglia, } \\
\text { PhD }\end{array}$ & $\begin{array}{l}\text { Fondazione IRCCS } \\
\text { Istituto } \\
\text { Neurologico Carlo } \\
\text { Besta, Italy }\end{array}$ & Author & $\begin{array}{l}\text { Acquisition of data } \\
\text { and revised the } \\
\text { manuscript for } \\
\text { intellectual content }\end{array}$ \\
\hline
\end{tabular}

Appendix (continued)

\begin{tabular}{llll}
\hline Name & Location & Role & Contribution \\
\hline $\begin{array}{lll}\text { Henry } \\
\text { Houlden, PhD }\end{array}$ & $\begin{array}{l}\text { UCL Queen } \\
\text { Square Institute of } \\
\text { Neurology, }\end{array}$ & Author & $\begin{array}{l}\text { Acquisition of data; } \\
\text { revised the } \\
\text { London, UK }\end{array}$ \\
& & $\begin{array}{l}\text { manuscript for } \\
\text { intellectual content; } \\
\text { and supervision of } \\
\text { the entire process }\end{array}$ \\
\end{tabular}

\section{References}

1. Nicolas G, Charbonnier C, Campion D, Veltman JA. Estimation of minimal disease prevalence from population genomic data: application to primary familial brain calcification. Am J Med Genet B Neuropsychiatr Genet 2018;177:68-74.

2. Ramos EM, Carecchio M, Lemos R, et al. Primary brain calcification: an international study reporting novel variants and associated phenotypes. Eur J Hum Genet 2018;26: 1462-1477.

3. Westenberger A, Klein C. The genetics of primary familial brain calcifications. Curr Neurol Neurosci Rep 2014;14:490.

4. Taglia I, Bonifati V, Mignarri A, Dotti MT, Federico A. Primary familial brain calcification: update on molecular genetics. Neurol Sci 2015;36:787-794.

5. Yao XP, Cheng X, Wang C, et al. Biallelic mutations in MYORG cause autosomal recessive primary familial brain calcification. Neuron 2018;98:1116-1123.e5.

6. Grangeon L, Wallon D, Charbonnier C, et al. Biallelic MYORG mutation carriers exhibit primary brain calcification with a distinct phenotype. Brain 2019;142:1573-1586.

7. Li H, Durbin R. Fast and accurate long-read alignment with Burrows-Wheeler transform. Bioinformatics (Oxford, England) 2010;26:589-595.

8. McKenna A, Hanna M, Banks E, et al. The Genome Analysis Toolkit: a MapReduce framework for analyzing next-generation DNA sequencing data. Genome Res 2010, 20:1297-1303.

9. Van der Auwera GA, Carneiro MO, Hartl C, et al. From FastQ data to high confidence variant calls: the Genome Analysis Toolkit best practices pipeline. Curr Protoc Bioinformatics 2013;43:11.10.1-11.10.33.

10. DePristo MA, Banks E, Poplin R, et al. A framework for variation discovery and genotyping using next-generation DNA sequencing data. Nat Genet 2011;43 491-498.

11. Danecek P, McCarthy SA. BCFtools/csq: haplotype-aware variant consequences. Bioinformatics (Oxford, England) 2017;33:2037-2039.

12. Yang H, Wang K. Genomic variant annotation and prioritization with ANNOVAR and wANNOVAR. Nat Protoc 2015;10:1556-1566.

13. Auton A, Auton A, Brooks LD, et al. A global reference for human genetic variation. Nature 2015;526:68-74.

14. Lek M, Karczewski KJ, Minikel EV, et al. Analysis of protein-coding genetic variation in 60,706 humans. Nature 2016;536:285-291.

15. Richards S, Aziz N, Bale S, et al. Standards and guidelines for the interpretation of sequence variants: a joint consensus recommendation of the American College of Medical Genetics and Genomics and the Association for Molecular Pathology. Genet Med 2015; 17:405-424

16. Arkadir D, Lossos A, Rahat D, et al. MYORG is associated with recessive primary familial brain calcification. Ann Clin Transl Neurol 2019;6:106-113.

17. Chen Y, Fu F, Chen S, et al. Evaluation of MYORG mutations as a novel cause of primary familial brain calcification. Mov Disord 2019;34:291-297.

18. Forouhideh Y, Müller K, Ruf W, et al. A biallelic mutation links MYORG to autosomal-recessive primary familial brain calcification. Brain 2019;142:e4

19. Peng Y, Wang P, Chen Z, Jiang H. A novel mutation in MYORG causes primary familial brain calcification with central neuropathic pain. Clin Genet 2019;95: 433-435.

20. Batla A, Tai XY, Schottlaender L, Erro R, Balint B, Bhatia KP. Deconstructing Fahr's disease/syndrome of brain calcification in the era of new genes. Parkinsonism Relat Disord 2017;37:1-10.

21. König P. Psychopathological alterations in cases of symmetrical basal ganglia sclerosis. Biol Psychiatry 1989;25:459-468.

22. Yamada M, Asano T, Okamoto K, et al. High frequency of calcification in basal ganglia on brain computed tomography images in Japanese older adults. Geriatr Gerontol Int 2013;13:706-710.

23. Datta K, Guan T, Gerace L. NET37, a nuclear envelope transmembrane protein with glycosidase homology, is involved in myoblast differentiation. J Biol Chem 2009;284 29666-29676.

24. GTEx Consortium. Human genomics. The genotype-tissue expression (GTEx) pilot analysis: multitissue gene regulation in humans. Science 2015;348:648-660.

25. Ramasamy A, Trabzuni D, Guelfi S, et al. Genetic variability in the regulation of gene expression in ten regions of the human brain. Nat Neurosci 2014;17:1418-1428. 


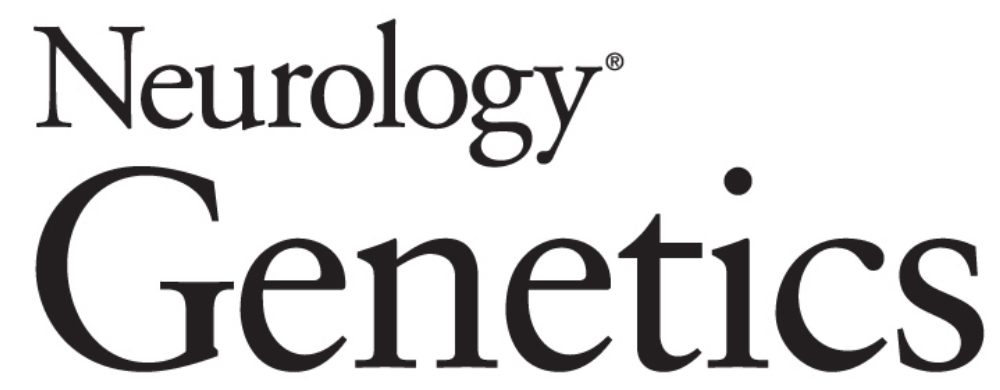

MYORG-related disease is associated with central pontine calcifications and atypical parkinsonism

Viorica Chelban, Miryam Carecchio, Gillian Rea, et al. Neurol Genet 2020;6;

DOI 10.1212/NXG.0000000000000399

This information is current as of February 20, 2020

Neurol Genet is an official journal of the American Academy of Neurology. Published since April 2015, it is an open-access, online-only, continuous publication journal. Copyright Copyright ( 2020 The Author(s). Published by Wolters Kluwer Health, Inc. on behalf of the American Academy of Neurology.. All rights reserved. Online ISSN: 2376-7839.

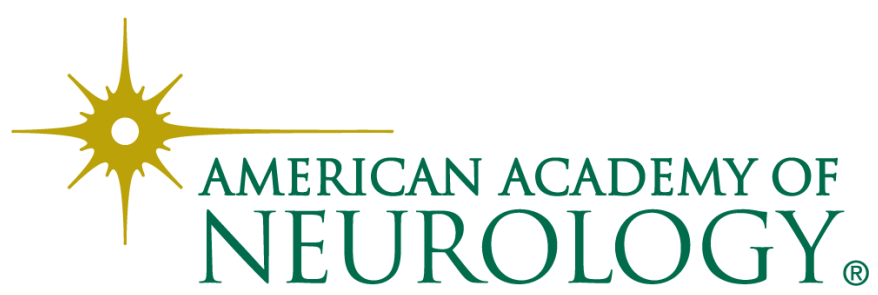




\section{Updated Information \& Services}

References

Subspecialty Collections

Permissions \& Licensing

Reprints including high resolution figures, can be found at: http://ng.neurology.org/content/6/2/e399.full.html

This article cites 25 articles, 3 of which you can access for free at: http://ng.neurology.org/content/6/2/e399.full.html\#\#ref-list-1

This article, along with others on similar topics, appears in the following collection(s):

All Clinical Neurology

http://ng.neurology.org//cgi/collection/all_clinical_neurology All Genetics

http://ng.neurology.org//cgi/collection/all_genetics

All Movement Disorders

http://ng.neurology.org//cgi/collection/all_movement_disorders

Basal ganglia

http://ng.neurology.org//cgi/collection/basal_ganglia

Parkinson's disease/Parkinsonism

http://ng.neurology.org//cgi/collection/parkinsons_disease_parkinsonis $\mathrm{m}$

Information about reproducing this article in parts (figures,tables) or in its entirety can be found online at:

http://ng.neurology.org/misc/about.xhtml\#permissions

Information about ordering reprints can be found online:

http://ng.neurology.org/misc/addir.xhtml\#reprintsus

Neurol Genet is an official journal of the American Academy of Neurology. Published since April 2015, it is an open-access, online-only, continuous publication journal. Copyright Copyright ( 2020 The Author(s). Published by Wolters Kluwer Health, Inc. on behalf of the American Academy of Neurology.. All rights reserved. Online ISSN: 2376-7839.

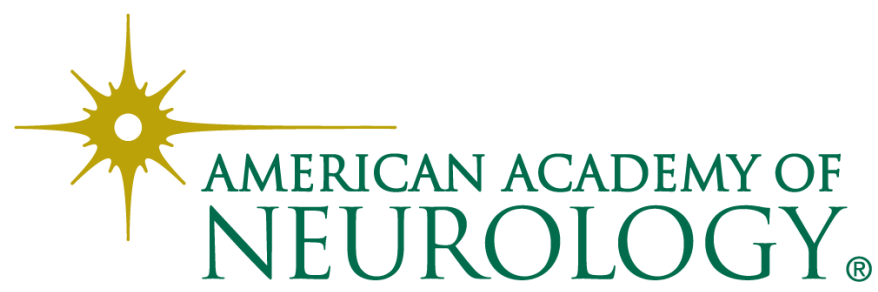

